DOI 10.22460/jpmi.v1i3.219-228

\title{
MENINGKATKAN KEMAMPUAN PENALARAN MATEMATIK SISWA SMP MELALUI PENDEKATAN PENEMUAN TERBIMBING
}

\author{
Amalia Septiani Hermawan', Wahyu Hidayat ${ }^{2}$ \\ ${ }^{1,2}$ IKIP Siliwangi, Jl. Terusan Jenderal Sudirman, Cimahi, Jawa Barat, Indonesia \\ ${ }^{1}$ ameliahermaw@gmail.com²wahyu@ikipsiliwangi.ac.id
}

\begin{abstract}
This research is based on the students' mathematical reasoning ability which is still very low. The importance of these abilities because it is one of the goals in learning mathematics. one of the alternative learning that can improve students' mathematical reasoning abilities is learning using guided discovery approach. The purpose of this study was to observe and examine the achievement of mathematical reasoning ability of junior high school students through guided discovery approach better than ordinary learning, observing and reviewing the improvement of mathematical reasoning ability of junior high school students through guided discovery approach better than ordinary learning. The method of this research is quasi method of experiment and research design using pretest and postes experiment and control class. The population in this study is the seventh grade students of SMP Negeri 9 Cimahi. The sample was taken only two classes by purposive sampling that is class VII $\mathrm{j}$ as experiment class and class VII $\mathrm{i}$ as control class. The instrument used in the research is a test of mathematical reasoning ability. The results show that the achievement of mathematical reasoning ability of junior high school students through guided discovery approach is better than ordinary learning, Improving mathematical reasoning ability of junior high school students through guided discovery approach is better than ordinary learning.
\end{abstract}

Keywords: Mathematical Reasoning, guided discovery

\begin{abstract}
Abstrak
Penelitian ini dilatar belakangi oleh kemampuan penalaran matematik siswa SMP yang masih sangat rendah. Pentingnya kemampuan tersebut karena merupakan salah satu tujuan dalam pembelajaran matematika. salah satu alternatif pembelajaran yang dapat meningkatkan kemampuan penalaran matematik siswa adalah pembelajaran yang menggunakan pendekatan penemuan terbimbing. Tujuan penelitian ini untuk mengamati dan menelaah pencapaian kemampuan penalaran matematik siswa SMP melalui pendekatan penemuan terbimbing lebih baik daripada pembelajaran biasa, mengamati dan menelaah peningkatan kemampuan penalaran matematik siswa SMP melalui pendekatan penemuan terbimbing lebih baik daripada pembelajaran biasa. Metode penelitian ini adalah metode kuasi eksperimen dan desain penelitian menggunakan pretes dan postes kelas eksperimen dan kontrol. Populasi dalam penelitian ini adalah siswa kelas VII SMP Negeri 9 Cimahi. Sampel diambil hanya dua kelas secara purposive sampling yaitu kelas VII j sebagai kelas eksperimen dan kelas VII i sebagai kelas kontrol. Instrumen yang digunakan dalam penelitian berupa tes kemampuan penalaran matematik. Hasil penelitian menunjukkan bahwa Pencapaian kemampuan penalaran matematik siswa SMP melalui pendekatan penemuan terbimbing lebih baik daripada pembelajaran biasa, Peningkatan kemampuan penalaran matematik siswa SMP melalui pendekatan penemuan terbimbing lebih baik daripada pembelajaran biasa.
\end{abstract}

Kata Kunci: Penalaran Matematis, Penemuan Terbimbing 
How to cite: Hermawan, A. S., \& Hidayat, W. (2018). Meningkatkan Kemampuan Penalaran Matematik Siswa SMP melalui Pendekatan Penemuan Terbimbing. JPMI - Jurnal Pembelajaran Matematika Inovatif, 1 (1), 7-12.

\section{PENDAHULUAN}

Matematika merupakan ilmu universal yang mempunyai peran penting dalam berbagai disiplin dan memajukan daya pikir manusia. Mata pelajaran matematika perlu diberikan kepada semua peserta didik mulai dari sekolah dasar untuk dapat membekali peserta didik dengan kemampuan berpikir logis, analitis, sistematis, kritis dan kreatif. Dalam perkembangan modern, matematika memegang peranan penting karena dengan bantuan matematika semua ilmu pengetahuan sempurna.

Wahyudin (Bani, 2011:4) mengemukakan bahwa salah satu kecenderungan yang menyebabkan sejumlah siswa gagal menguasai dengan baik pokok-pokok bahasan dalam matematika akibat siswa kurang menggunakan nalar yang logis dalam menyelesaikan soal atau persoalan matematika yang diberikan.

Menurut Sumarmo (Abdurahman, 2014:10), secara garis besar penalaran dapat digolongkan dalam dua jenis yaitu penalaran induktif dan penalaran deduktif. Penalaran induktif adalah suatu proses berpikir yang berupa penarikan kesimpulan umum (berlaku untuk semua/banyak) atas dasar pengetahuan tentang hal yang khusus (fakta), artinya dari fakta-fakta diturunkan suatu kesimpulan. Sementara penalaran deduktif adalah penarikan kesimpulan berdasarkan aturan yang disepakati. Nilai kebenarannya bersifat mutlak benar atau salah dan tidak keduanya bersama-sama. Menurut Schoenfeld (Hutajulu, 2010:23), matematika merupakan proses yang aktif, dinamik, generatif dan eksploratif. Berarti bahwa proses matematika dalam penarikan kesimpulan merupakan kegiatan yang membutuhkan pemikiran dan penalaran tingkat tinggi.

Burner (Sajidah, 2012:13) menganggap bahwa penemuan sesuai dengan pencarian pengetahuan secara aktif oleh manusia dan dengan sendirinya memberikan hasil yang paling baik. Berusaha sendiri untuk mencari pemecahan masalah serta pengetahuan yang menyertainya, menghasilkan pengetahuan yang benar-benar bermakna. Pembelajaran penemuan adalah rangkaian kegiatan pembelajaran yang menekankan pada proses berfikir secara kritis dan analitis untuk mencari dan menemukan sendiri jawaban yang sudah pasti dari suatu masalah yang dipertanyakan.

Menurut Herdian (Arsefa, 2014:20) pembelajaran penemuan terbimbing merupakan suatu model pengajaran yang menitikberatkan pada aktivitas siswa dalam belajar. Dalam proses pembelajaran dengan model ini, guru hanya bertindak sebagai pembimbing dan fasilitator yang mengarahkan siswa untuk menemukan konsep, dalil, prosedur, algoritma dan semacamnya. Pembelajaran penemuan adalah rangkaian kegiatan pembelajaran yang menekankan pada proses berfikir secara kritis dan analitis untuk mencari dan menemukan sendiri jawaban yang sudah pasti dari suatu masalah yang dipertanyakan.

Berdasarkan paparan diatas permasalahan dapat dirumuskan yaitu apakah pencapaian dan peningkatan kemampuan penalaran matematik siswa SMP melalui pendekatan kemampuan penalaran matematik lebih baik daripada pembelajaran biasa.

\section{METODE}


Berdasarkan permasalahan yang telah dikemukakan sebelumnya, jenis penelitian yang dilakukan adalah penelitian kuasi eksperimen. Pada kuasi eksperimen subjek tidak dikelompokkan secara acak. Pada penelitian ini ada dua kelas sampel penelitian yaitu kelas eksperimen dengan pembelajarannya menggunakan pendekatan penemuan terbimbing dan kelas kontrol menggunakan pembelajaran biasa. Pada awal dan akhir pembelajaran kedua kelas diberi tes sehingga desain penelitiannya adalah desain kelompok kontrol pretes-postes. Desain yang digunakan dalam penelitian ini menurut Ruseffendi (Hidayat: 2012)

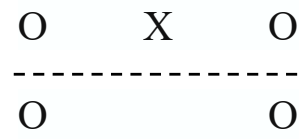

Keterangan:

O : Tes kemampuan Penalaran matematik

$\mathrm{X} \quad$ : Perlakuan pembelajaran pendekatan penemuan terbimbing

Populasi pada penelitian ini adalah seluruh siswa kelas VII pada salah satu SMP Negeri di Kota Cimahi. Dari populasi tersebut dipilih dua kelas sebagai sampel penelitian yang ditentukan berdasarkan purposive sampling dengan tujuan agar penelitian dapat dilaksanakan secara efektif dan efisien terurama dalam hal pengawasan, kondisi subyek penelitian, waktu penelitian yang ditetapkan, kondisi tempat penelitian serta prosedur perizinan. Sampel pada penelitian ini yaitu kelas VII-j sebagai kelas eksperimen dan VII-i sebagai kelas kontrol. Instrumen yang digunakan dalam penelitian ini adalah seperangkat soal uraian kemampuan penalaran matematik terdiri dari lima soal.

\section{HASIL DAN PEMBAHASAN}

\section{Hasil}

\section{Analisi Data Tes Awal}

Sebelum pembelajaran dilakukan, kedua kelas diberikan tes awal (pretes). Dari tes tersebut data-data yang akan diolah dan dianalisis dengan menggunakan bantuan Software Ms. Excel 2010 yaitu dengan mencari nilai rata-rata dan simpangan baku dari kedua kelas. Setelah diperoleh nilai rata-rata dan simpangan baku dari kedua kelas, berikut data hasil skor kemampuan penalaran.

Tabel 1. Statistik Deskriptif Hasil Skor Kemampuan Penalaran

\begin{tabular}{|c|c|c|c|c|c|c|}
\hline \multirow[b]{2}{*}{ Variabel } & \multicolumn{3}{|c|}{ Kelas Eksperimen } & \multicolumn{3}{|c|}{ Kelas Kontrol } \\
\hline & Pretes & Postes & $\begin{array}{l}\text { N- } \\
\text { Gain }\end{array}$ & Pretes & Postes & N-Gain \\
\hline $\mathrm{N}$ & 33 & 33 & 33 & 33 & 33 & 33 \\
\hline$X_{\max }$ & 14 & 20 & 1,00 & 11 & 20 & 1,00 \\
\hline$X_{\min }$ & 5 & 13 & 0,36 & 4 & 10 & 0,18 \\
\hline $\bar{x}$ & 9,18 & 16,67 & 0,69 & 8,45 & 14,61 & 0,54 \\
\hline$S$ & 2,34 & 2,12 & 0,19 & 1,42 & 2,45 & 0,20 \\
\hline
\end{tabular}


Selanjutnya akan dilakukan beberapa uji persyaratan menggunakan SPSS 22 dan Minitab 17 untuk mengetahui apakah pencapaian dan peningkatan kemampuan penalaran matematik siswa SMP melalui pendekatan penemuan terbimbing lebih baik daripada pembelajaran biasa. Selanjutnya untuk mengetahui kemampuan awal kelas eksperimen dan kelas kontrol dilakukan uji Mann-Whitney. Berikut ini adalah hasil pengolahan pretes uji Mann-Whitney:

Tabel 2. Hasil Uji Mann Whitney Data Pretes Kemampuan Penalaran Matematik

\begin{tabular}{lccccc}
\hline Kelas & $\mathrm{N}$ & $\bar{x}$ & $\mathrm{~S}$ & $\mathrm{P}-$ Value & Interpretasi \\
\hline Eksperimen & 33 & 9,18 & 2,34 & & \\
Kontrol & 33 & 8,45 & 1,42 & 0,1191 & $\mathrm{H}_{0}$ diterima \\
\hline
\end{tabular}

Dengan demikian dapat disimpulkan bahwa tidak terdapat perbedaan pada kemampuan awal (pretes) penalaran matematik siswa secara signifikan antara kelas eksperimen dan kelas kontrol.

\section{Analisis Data Tes Akhir}

Untuk menganalisis data postes menggunakan uji t karena data tersebut berdistribusi normal dan homogen. Berikut ini adalah hasil pengolahan uji signifikansi perbedaan dua rata-rata postes, sebagai berikut:

Tabel 3. Hasil Uji Perbedaan Dua Rata-rata Data Postes Kemampuan Penalaran Matematik

\begin{tabular}{llrlll}
\hline Kelas & $\mathbf{N}$ & $\overline{\boldsymbol{x}}$ & $\mathbf{S}$ & P-Value & Interpretasi \\
\hline Eksperimen & 33 & 16,67 & 2,12 & \multirow{2}{*}{0,000} & $\mathrm{H}_{0}$ ditolak \\
Kontrol & 33 & 14,61 & 2,45 & & \\
\hline
\end{tabular}

Sehingga dapat disimpulkan bahwa pencapaian kemampuan penalaran matematik siswa yang pembelajarannya menggunakan pendekatan penemuan terbimbing lebih baik daripada pembelajaran biasa.

\section{Analisis Data Skor N-Gain Ternormalisasi}

Untuk mengetahui peningkatan kemampuan penalaran matematik siswa SMP melalui pendekatan penemuan terbimbing lebih baik daripada pembelajaran biasa dilakukan dengan uji perbedaan dua rerata. Berikut ini adalah hasil pengolahan uji signifikansi perbedaan dua ratarata N-gain:

Tabel 4. Hasil Uji Perbedaan Dua Rata-rata Data N-Gain Ternormalisasi

\begin{tabular}{lcclll}
\hline Kelas & $\mathrm{N}$ & $\bar{x}$ & $\mathrm{~S}$ & $\mathrm{P}$-Value & Interpretasi \\
\hline Eksperimen & 33 & 0,69 & 0,19 & & \\
Kontrol & 33 & 0,54 & 0,20 & 0,017 & $\mathrm{H}_{0}$ ditolak
\end{tabular}

Berdasarkan Tabel 4 terlihat bahwa $\mathrm{H}_{0}$ ditolak, maka peningkatan kemampuan penalaran matematik siswa yang pembelajarannya menggunakan pendekatan penemuan terbimbing lebih baik daripada pembelajaran biasa.

\section{Pembahasan}


Penelitian ini bertujuan untuk melihat sejauh mana pencapaian kemampuan penalaran matematik siswa setelah pembelajaran dilakukan dan untuk melihat seberapa besar peningkatan kemampuan penalaran matematik yang diraih oleh siswa pada kelas eksperimen dan siswa pada kelas kontrol dengan menggunakan pembelajaran yang berbeda. Penelitian ini dilakukan di SMP Negeri 9 Cimahi sebanyak sepuluh kali pertemuan pada kedua kelas. Dua pertemuan digunakan untuk pretes-postes dan delapan pertemuan digunakan untuk kelas eksperimen dengan menggunakan pembelajaran pendekatan penemuan terbimbing, sedangkan kelas kontrol menggunakan pembelajaran biasa.

Berdasarkan analisis statistik deskriptif pretes dapat dilihat pada Tabel 2, nilai rata-rata atau mean kelas eksperimen lebih besar daripada kelas kontrol, namun selisih mean kelas kedua tersebut tidak terdapat perbedaan yang signifikan pada kemampuan awal penalaran matematik. Salah satu hal yang menyebabkan kurangnya kemampuan penalaran matematik adalah siswa kurang menggunakan nalar yang logis dalam menyelesaikan soal atau persoalan matematika yang diberikan, sehingga pada saat pretes siswa kebingungan dalam mengerjakan soal penalaran tersebut dengan benar.

Pada pertemuan selanjutnya kedua kelas mendapatkan pembelajaran, tetapi dengan perlakuan yang berbeda seperti yang sudah disebutkan pada uraian di atas.Setelah dilakukan pretes dan perlakuan, selanjutnya dilakukan postes pada kelas eksperimen dan kelas kontrol.

Berdasarkan hasil postes, nilai rata-rata atau mean kelas eksperimen lebih besar daripada kelas kontrol dan selisih mean kedua kelas tersebut terdapat perbedaan yang signifikan. Dapat dilihat pada Tabel 3 dan 4, ini berarti kemampuan penalaran matematik siswa yang memperoleh pembelajaran menggunakan pendekatan penemuan terbimbing tidak sama dengan siswa yang memperoleh pembelajaran biasa. Lebih tepatnya kemampuan penalaran matematik siswa yang pembelajarannya menggunakan pendekatan penemuan terbimbing lebih baik daripada siswa yang menggunakan pembelajaran biasa.

\section{KESIMPULAN}

Berdasarkan hasil penelitian dan analisis data selama pembelajaran dikelas eksperimen dan kelas kontrol, maka dapat diperoleh kesimpulan bahwa pencapaian dan peningkatan kemampuan penalaran matematik siswa SMP melalui pendekatan penemuan terbimbing lebih baik daripada pembelajaran biasa.

\section{DAFTAR PUSTAKA}

Abdurahman, D. (2014). Meningkatkan Kemampuan Penalaran dan Komunikasi serta Disposisi Matematik Siswa SMP melalui Pembelajaran Inkuiri Terbimbing. Tesis SPs UPI Bandung: Tidak diterbitkan.

Arsefa, D. (2014). Meningkatkan Kemampuan Pemahaman dan Penalaran Matematik serta Motivasi Belajar Siswa Sekolah Menengah Pertama melalui Pembelajaran Penemuan Terbimbing. Tesis SPs UPI Bandung: Tidak diterbitkan.

Bani, A. (2011). Meningkatkan Kemampuan Pemahaman dan Penalaran Matematik Siswa Sekolah Menengah Pertama melalui Pembelajaran Penemuan Terbimbing. Tesis SPs UPI Bandung: Tidak diterbitkan. 
Hidayat, W. (2012). Meningkatkan Kemampuan Berpikir Kritis dan Kreatif Matematik Siswa SMA melalui Pembelajaran Kooperatif Think-Talk-Write (TTW). Prosiding: Seminar Nasional Penelitian, Pendidikan dan Penerapan MIPA. UNY. Yogyakarta.

Hutajulu, M. (2010). Meningkatkan Kemampuan Pemahaman dan Penalaran Matematik Siswa Sekolah Menengah Atas melalui Model Pembelajaran Inkuiri Terbimbing. Tesis SPs UPI Bandung: Tidak diterbitkan.

Sajidah, Y. (2012). Menningkatkan Kemampuan Pemahaman dan Penalaran Matematik Siswa dengan Menggunakan Pendekatan Penemuan Terbimbing. Skripsi. STKIP Siliwangi Bandung: Tidak diterbitkan. 